\title{
The Applicability of Section 7 of the Charter to Oil and Gas Development in Alberta
}

\section{Nickie Vlavianos ${ }^{\star}$}

\section{Introduction}

When Albertans think about human rights in the context of oil and gas development, many think of Africa, and for good reason. Indeed, the tragic events that have unfolded in Sudan in recent years may come to mind. Few, however, will turn their minds to the possibility of human rights violations occurring in their own province. And yet, in at least three court applications over the past year or so, landowners have raised the spectre of the applicability of human rights law in the context of oil and gas development in Alberta. Specifically, the possibility of the application of section 7 of the Canadian Charter of Rights and Freedoms is at issue. ${ }^{1}$ Arguments have been based on both aspects of section 7 - the right to life, liberty, and security of the person, and the right not to be deprived thereof except in accordance with the principles of fundamental justice (or procedural fairness), including rights to a fair hearing, to reasonable notice, and to reasons for a decision. Although no definite ruling has yet emerged, in none of these cases was it suggested that section 7 is inapplicable in the context of the actual and potential environmental and health impacts of oil and gas development (or other industrial development for that matter). Where there might have been doubt about this issue before, there does not appear to be any now.

\section{The Graff Leave to Appeal Application}

In Graff v. Alberta (Energy and Utilities
Board) Barbara, Larry, and Darrel Graff (the "Graffs") applied to the Alberta Court of Appeal for leave to appeal a decision by the province's energy regulator, now the Energy Resources Conservation Board (ERCB). ${ }^{2}$ Decisions from the ERCB may be appealed to the Court of Appeal on a question of law or jurisdiction, with leave of the court. Leave will be granted where the applicant demonstrates that the question of law or jurisdiction raises a serious, arguable point. Subsumed in this test are four factors: (1) whether the point on appeal is of significance to the practice; (2) whether the point raised is of significance to the action itself; (3) whether the appeal is prima facie meritorious; and (4) whether the appeal will unduly hinder the progress of the action. ${ }^{3}$

The Graffs' leave to appeal application was related to an ERCB decision in which the board had refused the family's request for a review of a prior board approval authorizing the drilling of a gas well near their property. In their letters to the board, the Graffs stated that the proposed well would have adverse effects on their health and safety. Elsewhere, the Graffs have explained that their worries about further oil and gas activity near their home stem from concerns about the potential adverse effects of the activity on their already compromised medical condition (known as chemical encephalopathy). This condition is akin to asthma and is exacerbated by emissions from the venting, flaring, and incineration of natural gas; it also involves excessive sensitivity to chemicals. ${ }^{4}$ Among other things, the Graffs submitted to the board that approval 
of this well without allowing their concerns to be heard by the board would amount to a violation of their rights protected by section 7 of the Charter.

The board denied the Graffs' request for a review of the well approval on the basis that the family had failed to demonstrate that it was directly and adversely affected by the proposed well. Section 26 of the Energy Resources Conservation $A c t^{5}$ grants standing to be heard by the board on a well application to anyone whose "rights may be directly and adversely affected" by a board decision. In this case, the board noted that there was no hydrogen sulphide (sour gas) expected to be produced by the proposed well and that the Graffs' land was 18.7 kilometres away. According to the board, for participatory rights to be triggered there must be a reasonable connection between a party with special needs and the proposed application, and there was no such connection here. Responding to complaints about a possible breach of section 7 of the Charter, the board stated that the Graffs had not provided sufficient information to substantiate how their rights had been directly and adversely affected by the well.

Before the Court of Appeal, the Graffs sought leave to appeal the board's decision on a number of grounds including the claim that the board had erred in law or jurisdiction

\begin{abstract}
by jeopardizing the lives of Barbara and Darrell Graff by permitting proposed activities authorized by the well license such that their only opportunity for survival is to abandon their source of livelihood, in violation of their rights to life and security of the person guaranteed to them by section 7 of the Charter. ${ }^{6}$
\end{abstract}

During oral argument before Justice Hunt, counsel for the board acknowledged that its decision had been based on misinformation about the distance between the Graffs' land and the proposed well. Rather than 18.7 kilometers, the actual distance was 2.5 kilometers. Especially (but not only) because of this error, Justice Hunt granted leave to appeal the board's decision. Leave was granted on the grounds of the need to determine whether the ERCB had erred in law or jurisdiction: (a) by concluding that the Graffs were not directly and adversely affected by the proposed well; (b) in the board's interpretation and application of Directive 056 to the Graffs (regarding public consultation requirements); and (c) in failing to take into account the cumulative effect on the Graffs of the proposed well along with other wells near their property.

Although leave was granted to the Graffs to appeal the board's decision, leave was not granted specifically on the section 7 ground; nor did the court comment directly on the viability of section 7 in this context. Still, it was not explicitly rejected as lacking merit. Rather, with respect to the other grounds advanced (including that based on section 7 of the Charter), the court commented that it "was not satisfied that the test for leave has been made out in regard to some of the other proposed questions, and some are subsumed by the above three questions in any event."

\section{The Kelly Leave to Appeal Application}

Kelly v. Alberta (Energy and Utilities Board) began with two applications to drill two sour oil wells, which had been approved by the ERCB. Interveners in the board's proceeding applied to the Court of Appeal for leave to appeal the board's decision. ${ }^{8}$ Before Justice Berger, the applicants successfully raised two grounds of appeal. First, they argued that the board had acted without jurisdiction and erred in law by misconstruing and failing to apply its own directive (Directive 056) with respect to well-licensing applications, and in particular the requirements for public consultation that applicants must meet prior to submitting applications to the board.

Section 7 of the Charter was argued as the second ground of appeal. As summarized by Justice Berger, the thrust of the applicants' argument was that, in approving these wells, the board had acted without jurisdiction and erred in law by requiring residents to voluntarily relocate or to continue to live in their homes, while exposed to an unacceptable level of risk during the drilling and completion of the proposed wells. The company's evidence before the board was that at least eight families lived in an area of above-average risk. 
Justice Berger noted that the board had reached a number of critical conclusions about the level of risk involved in this case. In particular, the board had concluded that: (a) drilling the wells presented an inherent hazard for the residents in the area; (b) the company had an obligation to inform those living in the area of the risk posed by its operations; and (c) relocating residents was the best option to reduce the risk to them. Nonetheless, the board did not impose a condition on the well approvals that the residents who live in the areas of unacceptable risk be required to leave before drilling proceeds; nor did the board address the issue of compensation for those who chose to leave.

In these circumstances, the court concluded that it is at least arguable that the applicants should be entitled to advance an argument, on appeal, that section 7 of the Charter may be invoked, and that an infringement of section 7 has been made out if the applicants can establish three things. These are: (a) that there has been a real or imminent breach of the life, liberty, or security of the person; (b) that there are relevant principles of fundamental justice that apply; and (c) that the deprivation of the life, liberty, or security of the person has not been in accordance with relevant principles of fundamental justice. Citing the Supreme Court of Canada decisions in Charkaoui v. Canada (Citizenship and Immigration), Chaoulliv. Quebec (Attorney General), and Godbout v. Longueuil (City), ${ }^{9}$ Justice Berger concluded that the Charter argument satisfied the test for leave, namely, that it raised a serious arguable point which has a "reasonable prospect of success." 10

In granting leave to appeal on this ground, Justice Berger acknowledged that the applicants had not raised section 7 of the Charter before the board, nor had proper notice of an intention to raise a constitutional question been given. ${ }^{11}$ In Justice Berger's view, this was of no consequence because, as he stated, it is in part the board's findings of fact that had given rise to the section 7 argument in this case. Justice Berger's approach on this procedural point is correct. One cannot give advance notice of a Charter issue which arises after the board has exercised its discretion and has rendered its decision in a particular case. Indeed, parties are entitled to presume that statutory delegates like the ERCB will exercise their discretionary powers in ways that do not violate the Charter. ${ }^{12}$

\section{The Domke Leave to Appeal Application}

In Domke v Alberta (Energy Resources Conservation Board), a group of landowners sought leave to appeal a decision by the ERCB approving the drilling of two level-two critical sour wells. ${ }^{13}$ Before the board, the landowners had objected to the wells because of concerns about health and safety, air and water quality, environmental impacts, effects on property value, and the adequacy of emergency response planning.

Invoking section 7 of the Charter, the landowners had argued that the inherent health and safety risks involved in the drilling and operation of these two wells meant that board approval would result in a violation of the right to life, liberty, and security of landowners living near the wells. This would occur because the landowners would be placed in a situation of unacceptable and unnecessary risk. Before the board, the landowners had also argued that breaches of the second part of section 7 (the principles of fundamental justice or procedural fairness) had occurred in a number of ways. As a result of these breaches, they did not have all of the relevant information necessary to adequately understand the risks associated with these wells, and to participate fully and effectively in the hearing before the board. In particular, the landowners submitted that a lack of procedural fairness had occurred (or would occur) because: (a) the board had not compelled the company to answer certain information requests by the landowners; (b) the board had failed to provide the landowners and the public with a complete list of the hydrogen sulphide (sour gas) content of wells drilled in the area; and (c) the company had invoked section 12.150 of the Oil and Gas Conservation Regulation (OGCR), ${ }^{14}$ which authorized the company and the board to keep information about these wells confidential for a period of one year. The landowners said this regulation violated section 7 of the Charter. 
Rejecting each of these arguments, the ERCB approved the well applications and the landowners applied to the Court of Appeal for leave to appeal the board's decision. The landowners did so on a number of grounds including the board erring in law by concluding that there was no section 7 Charter violation in this case, and by misapplying the test for determining whether section 12.150 of the OGCR violates section 7 of the Charter. Unlike prior landowners' leave to appeal applications, Justice Ritter refused to grant leave to appeal in this case.

With respect to the alleged section 7 violation, Justice Ritter concluded that the board's analysis was "unassailable." 15 In his view, the board had articulated the correct test for a section 7 analysis and it had applied this test to the facts correctly. Although Justice Ritter acknowledged that future risk of infringement can constitute the basis for a breach of section 7 , he noted that in this case the ERCB had considered the potential risk to be minimal. Moreover, said the court, the board had considered that the required emergency planning zone would further minimize the risk and that those who lived close to the wells had the option of temporarily relocating during drilling. According to Justice Ritter, what the landowners disagreed with was the board's assessment of risk, which is a fact-laden exercise involving the board's expertise. It would be granted substantial deference on any appeal, rendering the appeal prima facie without merit.

On the issue of whether section 12.150 of the OGCR has the effect of breaching the landowners' section 7 Charter rights, Justice Ritter also concluded that this was not a meritorious ground of appeal. Section 12.150 allows well information required by the ERCB to be kept confidential for one year to give operators a period of time during which they enjoy an advantage over competitors. Before Justice Ritter, it was argued that because the landowners would not have the right to access the company's records for one year they would not know if they were facing potential risks that were higher than the anticipated rates of sour gas. The landowners submitted that this constituted a future-risk type of section 7 Charter breach, and that the principles of fundamental justice demanded disclosure of this information.

Justice Ritter disagreed. He noted that the landowners had not adduced any evidence to show any likelihood that gas volumes would be greater than projected volumes. To his mind, in the absence of such evidence, a prospective breach could not be established. But, he said, the evidentiary burden is not an impossible one for landowners to meet. Coupled with expert evidence, it might be possible for landowners to show that all wells in a given area, or drilled in a particular formation, result in gas volumes well beyond those projected in the initial licensing process.

Although leave to appeal was not granted in this decision, from the point of view of the applicability of section 7 of the Charter, it is noteworthy that neither Justice Ritter (nor the ERCB for that matter) suggested that section 7 has no application in the context of oil and gas operations. Previously, the question of whether section 7 might apply in the context of the health and environmental risks associated with oil and gas development was an open one. Now we know that it does apply and that it might provide a remedy in an appropriate case.

\section{Concluding Remarks}

There is something troubling about Justice Ritter's analysis in the Domke case (discussed above). On the one hand, he concludes that landowners might be able to meet the evidentiary burden required to establish a section 7 Charter breach if they have the right evidence. On the other hand, Justice Ritter condones the fact that in that particular case, necessary well information was either not provided to the landowners or was not available. One wonders how landowners could ever meet the evidentiary burden Justice Ritter refers to if they are not given the pertinent information, or if they receive it too late to make meaningful use of it. Also discomforting is the discussion in the case about voluntary relocation. Justice Ritter stated that this option was something the ERCB took into account in deciding that the risk was minimal in that case. But it is counterintuitive to say that the risk is minimal because people can simply move 
out of their homes if they want to. Of course the risk is minimal if there is no one around to experience it. But how easy is it for people to simply relocate, even temporarily? There was also no discussion in the case about compensation for this "voluntary" relocation.

Clearly, there are significant issues lurking behind these cases of landowners in Alberta feeling the impact of intensifying oil and gas development near or on their land. That these are very real concerns is obvious given the resort to section 7 of the Charter. There is no doubt that people tend to resort to mechanisms of human rights protection when the current process is failing them, or when they believe that what is at stake is something critically important, something which speaks to the intrinsic worth and dignity of human beings.

That said, section 7 of the Charter may not be a panacea in all cases for landowners looking for ways to deal with the increasing pressures of oil and gas development. There are several causal and factual hurdles that will have to be overcome in any given case. In particular, it remains to be seen whether a court would accept that it is the ERCB's approval of particular oil and gas facilities, and not the subsequent operations by the company, which may result in the imminent infringement of life, liberty, and security of the person. The law is clear that the Charter applies only to government and not to private actors. A court will also have to consider the principles of fundamental justice in this context. These principles typically afford procedural protections before a deprivation of life, liberty, or security of the person will be justified. Whether a court would find that these procedural guarantees were not met in situations where landowners were given an opportunity to be heard by the ERCB remains to be seen. All eyes are now on the pending Kelly appeal.

\section{Notes}

* Assistant Professor, Faculty of Law, University of Calgary, and Research Associate, Canadian Institute of Resources Law, University of Calgary, e-mail:nvlavian@ucalgary.ca.

1 Canadian Charter of Rights and Freedoms, Part I of the Constitution Act, 1982, being Schedule B to the Canada Act, 1982 (U.K.), 1982, c. 11 [Charter]. Graffv. Alberta (Energy and Utilities Board), 2007 ABCA 246 (CanLII) [Graff]. The ERCB replaced the Energy and Utilities Board (EUB) in January 2008.

3 Atco Electric Limited v. Energy and Utilities Board (Alberta), 2002 ABCA 45 (CanLII).

4 See Graff v. Alberta (Energy and Utilities Board), 2007 ABCA 20 (CanLII).

5 R.S.A. 2000 , c. E-10.

6 Supra note 2 at para. 11.

$7 \quad$ Ibid. at para. 17. Ultimately, the appeal by the Graffs was dismissed by the Court of Appeal on the basis that the family had failed to provide the board with sufficient medical evidence to make out their claim of being "directly and adversely affected" by the decision on the well application. The panel hearing the appeal emphasized that parties requesting standing before the ERCB must provide at least some relevant evidence to support their claim of being "directly and adversely" affected. The court made no comment on the applicability of section 7 of the Charter in this context. See Graff v. Alberta (Energy and Utilities Board), 2008 ABCA 119 (CanLII).

8 Kelly v. Alberta (Energy and Utilities Board), 2008 ABCA 52 (CanLII) [Kelly].

9 Charkaoui v. Canada (Citizenship and Immigration), 2007, SCC 9, [2007] 1 S.C.R. 350 (CanLII), Chaoulliv. Quebec (Attorney General), 2005 SCC 35, [2005] 1 S.C.R. 791 (CanLII), and Godbout v. Longueuil (City), 1997 SCC 335, [1997] 3 S.C.R. 844 (CanLII).

10 Supra note 8 at para. 2.

11 See Administrative Procedures and Jurisdiction Act, R.S.A. 2000, c. A-3, s. 12.

12 At the time of writing, the appeal in Kelly had yet to be heard. However, the company involved had withdrawn its well applications to the ERCB, leaving the status of the appeal uncertain. The company has also been removed as a party to the appeal: see Kelly v. Alberta (Energy and Utilities Board), 2008 ABCA 410.

13 Domke v. Alberta (Energy Resources Conservation Board), 2008 ABCA 232 (CanLII) [Domke].

14 A.R. 151/71 [the OGCR].

15 Supra note 13 at 27. 